\title{
RELATIONSHIP BETWEEN PLASMA CONCENTRATIONS OF ESTRADIOL-17B AND PROGESTERONE AND THE DISTRIBUTION OF EPITHELIAL AND INFLAMMATORY CELLS IN THE EXTERNAL OPENING OF THE RIVER BUFFALOES' UTERINE CERVIX DURING THE GESTATIONAL PERIOD
}

\author{
M. GOLI ${ }^{1}$, E. AYEN ${ }^{2}$, S. HASSANZADEH ${ }^{3}$ \& M. H. KHADEM ANSSARI ${ }^{4}$
}

${ }^{1}$ Department of Clinical Science, Faculty of Veterinary Medicine, Razi University, Kermanshah, Iran; ${ }^{2}$ Department of Clinical Science, Faculty of Veterinary Medicine, Urmia University, Urmia, Iran; ${ }^{3}$ Department of Histology, Faculty of Veterinary Medicine, Urmia University, Urmia, Iran; ${ }^{4}$ Department of Clinical Pathology, Faculty of Medicine, Medical Science University of Urmia, Urmia, Iran

\section{Summary}

Goli, M., E. Ayen, S. Hassanzadeh \& M. H. Khadem Anssari, 2021. Relationship between plasma concentrations of estradiol- $17 \beta$ and progesterone and the distribution of epithelial and inflammatory cells in the external opening of the river buffaloes' uterine cervix during the gestational period. Bulg. J. Vet. Med., 24, No 3, 365-375.

\begin{abstract}
Changes in the distribution of the epithelial and inflammatory cells in the external opening of the uterine cervix in river buffaloes at three different occasions during the gestation period were investigated by light microscopic evaluation of mucus smears prepared by wet swab sampling and Giemsastained. Forty five pregnant river buffaloes that were in the first $(n=15)$, second $(n=15)$ and third $(n=15)$ approximately equal parts of their gestation period were sampled twice concurrently by individual wet swabs from the external opening of the uterine cervix. Five smears were prepared from each sample. Immediately after mucus sampling, blood samples were obtained from the jugular vein of each animal, centrifuged immediately and stored at $-20{ }^{\circ} \mathrm{C}$ to assay the plasma levels of estradiol$17 \beta$ and progesterone. The results showed that changes in the percentage of the vacuolated and nonvacuolated epithelial cells, lymphocytes, eosinophils, and basophils were not statistically significant between the groups, which suggests that as the pregnancy progressed, changes in the blood levels of estradiol-17 $\beta$ and progesterone had little or no effect on the distribution of these cells in the region, but changes in the percentage of neutrophils were statistically significant between the groups. It was also found that changes in the percentage of macrophages between the second and third trimesters of the gestation period were not significant, but the difference between the first and the other trimesters was statistically significant. It was concluded that the percentages of neutrophils and macrophages increase significantly as the plasma concentrations of progesterone decrease during the gestation.
\end{abstract}

Key words: epithelial cells, estradiol-17 $\beta$, gestation, inflammatory cells, progesterone, river buffalo, uterine cervix 


\section{INTRODUCTION}

Infiltration of inflammatory cells into the cervical tissue is one of the main histological features observed in the cervix immediately after birth or in the late stages of normal cervix ripening. The influx of inflammatory cells is a major regulatory event in the initiation of cervical ripening during normal parturition (Timmons \& Mahendroo, 2006). Cervical structure remodelling at parturition resulted in the rapid opening known as cervical dilation, characterised by an infiltration of neutrophils and macrophages (Stygar et al., 2001; Osman et al., 2003). Parturition in sheep was associated with leukocytic invasion of the cervix, suggesting that leukocytes may participate in cervical connective tissue reorganisation (Owiny et al., 1995).

Inflammatory cells, such as neutrophils, macrophages, and eosinophils, are proposed to play an important role in the synthesis of cytokines and proteolytic enzymes that regulate the ripening process (Mackler et al., 1999). These cells are recruited to affected tissue from circulating blood. The invasion of the inflammatory cells into the cervical stroma is negatively regulated by progesterone (P4) (Timmons \& Mahendroo, 2006). The immunosuppressive effects of $\mathrm{P} 4$ have been recognised for more than 50 years (Black et al., 1953). There are increased numbers of neutrophils within the cervical stroma late in pregnancy, as reported in rodents and other species (Timmons \& Mahendroo, 2006).

It has been reported that in the mouse, increased numbers of macrophages were found in cervices at the end of pregnancy (day 18) (Mackler et al., 1999). In adult rats, macrophages increased in the uterine cervix towards the end of pregnancy, reaching maximum values just before par- turition (Bosquiazzo et al., 2005). Along the second half of pregnancy, a steady increase was observed in macrophage density with highest values just before parturition and temporally associated with P4 levels decrease (Taya \& Greenwald, 1981). This is in agreement with the results supporting the concept that P4 acts as a powerful negative regulator of macrophages (Hunt et al., 1998). A similar increase in macrophage numbers before parturition has been reported in mice and it was suggested that macrophages migrated from the uterine endometrium as a pathway to facilitate cervical relaxation (Mackler et al., 1999). Although the function of macrophages in the uterine cervix remains unclear, the recruitment of macrophages in the cervical stroma at the end of pregnancy suggests their participation in the processes required for a successful delivery. In contrast with the increase in macrophage density in the uterine cervix along pregnancy, the numbers of mast cells decreased (Bosquiazzo et al., 2005).

The presence of estrogen receptor (ER) and progesterone receptor (PR) during early development in oviduct, uterus and cervix has been mainly described in rodents (Yamashita et al., 1989; Greco et al., 1993; Shuanfang, 1994; Jefferson et al., 2000). Receptors for estradiol-17 $\beta$ (E2) (ER) (Nephew et al., 2000; Romans et al., 2002) and P4 (PR) (Ohta et al., 1993) have been reported to be present in epithelial cells and subepithelial stromal cells in rodent reproductive tract (Lee \& Sherwood, 2005). Uterine ER $\alpha$ expression was detected during foetal and postnatal ewe development (Taylor et al., 2000). The function of the cervix during various stages of the estrous cycle is regulated by circulating steroid hormones through their 
specific receptors (Stanchev et al., 1984; Klauke \& Hoffmann, 1992). Estrogens are known to have direct and indirect effects on vascular membranes. They induce vasodilatation and an increased ovarian and uterine blood flow in mares (Bollwein et al., 2002), sheep (Brown \& Mattner, 1977; Rosenfeld, 1980), and guinea pigs (Sjoquist et al., 1977) by complex processes such as inhibition of proliferation and migration of smooth muscle cells, an increased endothelial regeneration, modulation of inflammatory response and inhibition of aggregation and adhesion of thrombocytes (Joswig, 2000).

Immunocompetent cells are responsible for cellular and humoral infection protection (Isaacson \& Wright, 1984). Changes in the distribution of immunocompetent cells, such as granulocytes, lymphocytes, mast cells and macrophages, have been described in the uterine horns and cervical tissue along pregnancy, parturition and postpartum (Yellon et al, 2003; Varayoud et al., 2004). In general, eosinophilic granulocytes are thought to be involved in local immuno-reactivity by influencing the tissue permeability (Kelly, 1994; Wehrend et al., 2005).

Although changes in the cytological features of the cervix during the various stages of the oestrous cycle and during pregnancy have been thoroughly studied in women and some animal species (as models for humans), studies in buffaloes are rare. To our knowledge no study has been done about the changes in the distribution of the epithelial and inflammatory cells in the external opening of the river buffaloes' uterine cervix during different parts of gestation period.

\section{MATERIALS AND METHODS \\ Animals}

The present study was performed on forty five multiparous pregnant Azari river buffaloes with body condition scores ranging from 3.5 to 3.8 based on a five-point scale $(1=$ emaciated and $5=$ obese) (Edmonson et al., 1989), which belonged to the North and Northwest Buffalo Breeding Center (Jebel Station) located in Urmia city, West Azarbaijan, Iran, in 2005. The animals were in different stages of the gestation period, weighed $470 \pm 17 \mathrm{~kg}$, were kept in a free stall, fed a total mix ration to meet their nutritional requirements and had free access to drinking water all the time. The artificial insemination data of the animals were obtained from the farm records and the pregnancy status of each animal was confirmed by rectal palpation. The animals were between 6-7 years of age and were assigned to three groups according to their pregnancy stages: animals in group $1(\mathrm{G} 1, \mathrm{n}=15)$, group $2(\mathrm{G} 2$, $\mathrm{n}=15)$ and group $3(\mathrm{G} 3, \mathrm{n}=15)$ were in the first, second and last approximately equal parts of their gestation period, respectively. The experiment was conducted during winter.

\section{Ethics approval}

The experiment was approved by the Animal Ethics Committee of Urmia University, Iran.

\section{Samples collection}

Mucus samples were obtained from the external opening of the uterine cervix by swabs after restraining each animal in a box and washing and disinfecting its perineum and vulva. Then a sterile glass speculum was inserted into the vagina, so that the external opening of the cervix was revealed. Two swab samples were taken 
from the external opening of the uterine cervix of each animal under caudal epidural anaesthesia by rotating the swabs clockwise in contact with the wall of the external opening of the cervix and then five smears were prepared by rolling each swab on five light microscope glass slides, so a total of 150 smears were prepared for each group. The slides were dried in the ambient temperature, fixed by methyl alcohol and stained by Giemsa's staining method for cytological examinations. A separate microbial swab sample was also taken from the external opening of each buffalo's uterine cervix and sent to the microbiology laboratory of the Faculty of Veterinary Medicine, Urmia University in order to determine whether the presence of the inflammatory cells in the area was due to the stage of pregnancy or caused by the presence of infection. A blood sample was obtained from the jugular vein of each animal into a heparinised tube in order to assay the plasma concentrations of P4 and E2. The blood samples were centrifuged immediately after collection and the plasma samples were stored at $-20{ }^{\circ} \mathrm{C}$ until assayed. Plasma concentrations of E2 and P4 were assayed by radioimmunoassay (LIAISON ${ }^{\circledR}$ Estradiol II Gen and LIAISON ${ }^{\circledR}$ Progesterone II Gen, respectively; DiaSorin S.p.A., Italy). In addition, a blood smear was also prepared from each animal in order to perform differential blood count and evaluate the results in association with the microbiologic results.

\section{Cytological evaluation}

The stained mucus smears (Fig. 1) were evaluated by a light microscope (Olympus, Tokyo, Japan) at $\times 100, \times 400$ and $\times 1000$ magnification to identify the different types of cells and to determine the percentages of the inflammatory and epithelial cells of the external opening of the uterine cervix in the different stages of buffalos' gestational period. The cells present on ten random microscopic fields $\left(1 \mathrm{~mm}^{2}\right)$ of each smear were counted and the average numbers of each cell type

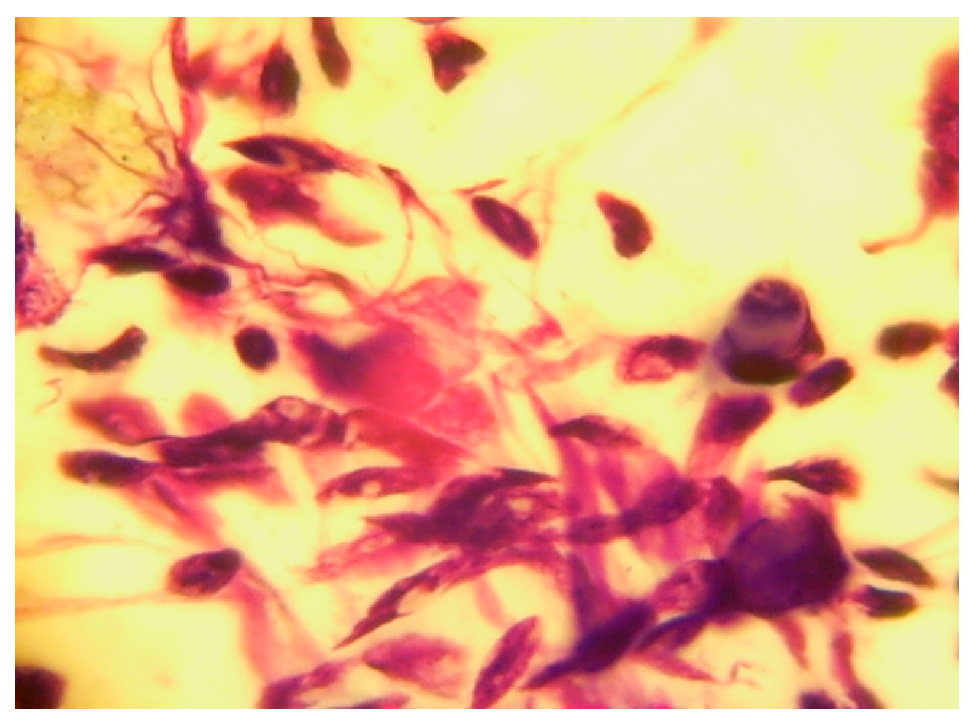

Fig. 1. A mucus smear prepared from the external opening of the uterine cervix of a pregnant buffalo, Giemsa's staining method (light microscope, $\times 1000$ ). 
were determined on each smear and finally on all smears of each group.

\section{Statistical analysis}

All data were analysed using one-way ANOVA to assess differences between means. Duncan's test was used to determine if there were any significant differences in the percentages of inflammatory and epithelial cells of the external opening of the cervix among the groups. The level of significant was set at $\mathrm{P}<0.05$.

\section{RESULTS}

Mean plasma E2 concentrations in G2 were significantly higher than those in G1 and G3 $(\mathrm{P}<0.05)$ but the difference between G1 and G3 was not significant $(\mathrm{P} \geq 0.05)$ (Table 1). Table 1 shows also that mean plasma $\mathrm{P} 4$ concentrations in $\mathrm{G} 1$ exceeded significantly those in G2 or G3 $(\mathrm{P}<0.05)$.
The difference between G2 and G3 was insignificant $(\mathrm{P} \geq 0.05)$.

Mean percentages of the non-vacuolated and vacuolated epithelial cells and lymphocytes of the external opening of the cervix was not significantly different in the three groups $(\mathrm{P} \geq 0.05)$ (Table 2$)$.

Mean percentages of monocytes (macrophages) between $\mathrm{G} 2$ and $\mathrm{G} 3$ did not differ significantly $(\mathrm{P} \geq 0.05)$, but those between $\mathrm{G} 1$ and the two other groups did $(\mathrm{P}<0.05)$. In other words, the monocyte counts and percentage increased significantly as gestation age advanced (Fig. 2).

Mean percentage of neutrophils in G3 was higher than that in G2 and the latter higher than that in G1 (Table 2). In other words, the neutrophil counts and percentage increased significantly as gestation age increased $(\mathrm{P}<0.05)$. Mean percentages of eosinophils and basophils in the smear samples prepared from the external opening secretions of the uterine cervix did not

Table 1. Plasma concentrations of estradiol-17 $\beta$ and progesterone in the three approximately equal parts of the river buffalo' gestational period (mean \pm SEM; $n=15$ )

\begin{tabular}{lclc}
\hline Hormone & Group 1 $\left(1^{\text {st }}\right.$ part $)$ & Group 2 $\left(2^{\text {nd }}\right.$ part $)$ & Group 3 $\left(3^{\text {rd }}\right.$ part $)$ \\
\hline Estradiol-17ß $(\mathrm{pg} / \mathrm{mL})$ & $56.00 \pm 3.50^{\mathrm{a}}$ & $88.47 \pm 12.38^{\mathrm{b}}$ & $53.19 \pm 7.49^{\mathrm{a}}$ \\
Progesterone $(\mathrm{ng} / \mathrm{mL})$ & $6.03 \pm 0.16^{\mathrm{a}}$ & $3.58 \pm 0.24^{\mathrm{b}}$ & $2.94 \pm 0.25^{\mathrm{b}}$ \\
\hline
\end{tabular}

${ }^{\mathrm{a}, \mathrm{b}}$ Different superscript letters within a row differ significantly.

Table 2. Percentages of different cell types in the external opening secretions of river buffalo' uterine cervix in the three approximately equal parts of pregnancy (mean $\pm S E M ; n=15$ )

\begin{tabular}{llll}
\hline Type of cell & Group 1 $\left(1^{\text {st }}\right.$ part $)$ & Group 2 $\left(2^{\text {nd }}\right.$ part $)$ & Group $3\left(3^{\text {rd }}\right.$ part $)$ \\
\hline Non-vacuolated epithelial cells & $61.52 \pm 4.91^{\mathrm{a}}$ & $68.55 \pm 2.76^{\mathrm{a}}$ & $71.00 \pm 2.34^{\mathrm{a}}$ \\
Vacuolated epithelial cells & $6.94 \pm 1.77^{\mathrm{a}}$ & $8.46 \pm 2.48^{\mathrm{a}}$ & $7.14 \pm 1.55^{\mathrm{a}}$ \\
lymphocytes & $8.31 \pm 1.89^{\mathrm{b}}$ & $6.97 \pm 1.65^{\mathrm{b}}$ & $12.33 \pm 2.61^{\mathrm{a}}$ \\
Macrophages & $9.33 \pm 2.40^{\mathrm{b}}$ & $10.70 \pm 1.70^{\mathrm{b}}$ & $1.94 \pm 1.14^{\mathrm{a}}$ \\
Neutrophils & $16.72 \pm 5.13^{\mathrm{c}}$ & $7.81 \pm 2.28^{\mathrm{b}}$ & $4.76 \pm 1.63^{\mathrm{a}}$ \\
Eosinophils & 0 & 0 & 0 \\
Basophils & 0 & 0 & 0 \\
\hline
\end{tabular}

${ }^{\mathrm{a}, \mathrm{b}, \mathrm{c}}$ Different superscript letters within a row differ significantly. 


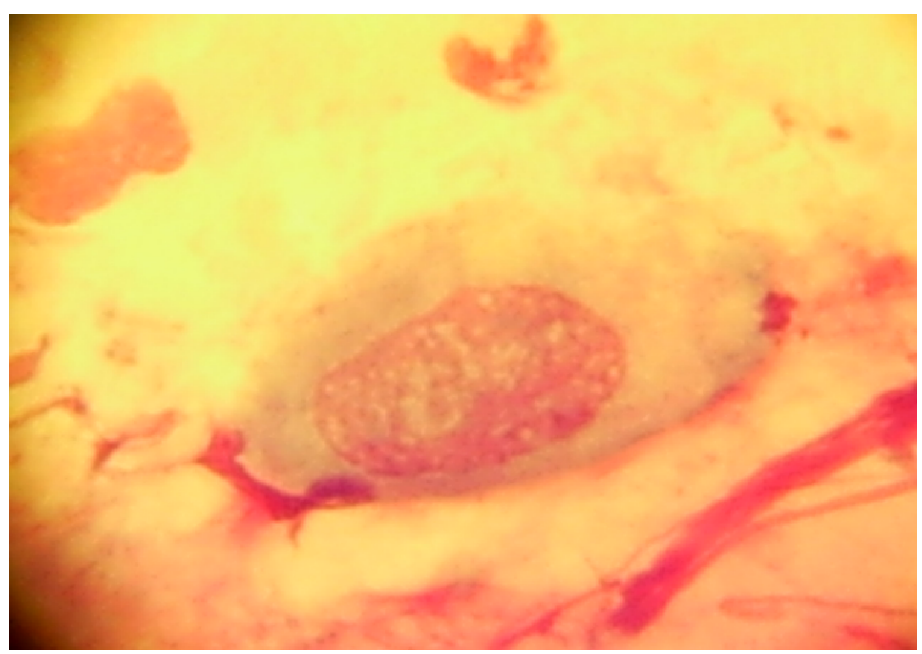

Fig. 2. A macrophage in the mucus smear prepared from the external opening of the uterine cervix of a pregnant buffalo, Giemsa's staining method (light microscope, $\times 1000$ ).

differ significantly among the three groups $(\mathrm{P} \geq 0.05)$ (Table 2).

Differential cell counts on the blood smears and examinations of the microbiologic cultures of the cervical external opening secretion showed no abnormality.

\section{DISCUSSION}

The results showed that the percentage of the non-vacuolated epithelial cells decreased as the pregnancy age increased, but this decrease was not statistically significant. Therefore, the counts of the nonvacuolated epithelial cells of the external opening of the uterine cervix in pregnant water buffaloes did not change significantly during the gestational period, which indicates the steady effects of progesterone on this type of cervical epithelial cell in this area. In other words, although progesterone concentrations decreased and estradiol-17 $\beta$ concentrations increased significantly during the second stage in comparison to the first stage of pregnancy, the decrease in progesterone and the in- crease in estrogen concentrations had no significant effect on the changes in the number of the epithelial cells in the external opening of the uterine cervix of the river buffalos during the gestational period.

On the other hand, the percentage of epithelial cells (vacuolated and nonvacuolated) of the external opening of the uterine cervix was higher than that of the other cell types in the three stages of the gestational period. These findings are in agreement with those reported previously by Ahmadi et al. (2000), since in both pregnancy and luteal phase of the estrus cycle the external opening of the uterine cervix is under the influence of progesterone and progesterone concentrations in plasma and milk increase during the first few days of pregnancy in a manner similar to that occurring in the early luteal phase of the non-pregnant animal (Ball \& Peters, 2004).

Although the percentage of the vacuolated epithelial cells of the external opening of the cervix in G2 was higher than those of the other groups (G1 and G3), the 
differences were not statistically significant and suggested the steady hormonal effects of E2 and P4 on this cell type in the external opening of the uterine cervix during the pregnancy in river buffaloes. In a study, blocking the actions of estrogen and progesterone with subcutaneous injections of the estrogen-receptor antagonist ICI 182,780 (ICI) and the progesteronereceptor antagonist RU486, respectively, to rats at 3-day intervals during the second half of pregnancy led to decreased rates of proliferation and increased rate of apoptosis of both cervical epithelial and stromal cells during late pregnancy. However, blocking the actions of progesterone had the opposite effects on apoptosis of both cervical epithelial and stromal cells during the middle of pregnancy. Therefore, estrogen and progesterone contribute to the increase in the cervical cell content during late pregnancy by both promoting proliferation and inhibiting apoptosis of cervical cells. On the other hand, the elevated serum levels of progesterone during the second half of pregnancy may also regulate cervical growth (Lee \& Sherwood, 2005). Another study demonstrated that administration of the progesterone antagonist RU480 to ovariectomised pregnant rats on day 22 resulted in a tendency for increased cervical wet weight (Zhao \& Sherwood, 2004).

In the present study the differences in the percentages of lymphocytes between the groups were not statistically significant, although the counts of lymphocytes in the first stage of pregnancy (G1) exceeded those in the other stages (G2 and G3). Also, the counts of lymphocytes in G2 were lower vs the other groups. On the other hand, the most abundant cells in G1 were the non-vacuolated epithelial cells and lymphocytes, respectively.
The percentage of macrophages increased markedly in G2 and G3 in comparison with G1. This increase suggested a statistically significant difference between either G2 or G3 on one hand vs G1 on the other. This finding is inconsistent with a study reporting that tissue macrophages were not increased in the cervix until after birth (Timmons \& Mahendroo, 2006), but other studies have reported a decline in collagen concentration as a result of increased activity of collagenases and other proteolytic enzymes. These proteases are present in cervical fibroblasts as well as polymorphonuclear leukocytes and macrophages (Junqueira et al., 1980; Rajabi et al., 1991; Sato et al., 1991; Hertelendy \& Zakar, 2004). Also, this finding is in agreement with the results of several other studies in demonstrating that macrophage counts increased in the uterine cervix along the second half and towards the end of pregnancy with highest values just before parturition, temporally associated with the decrease in P4 levels (Taya \& Greenwald, 1981; Mackler et al., 1999; Bosquiazzo et al., 2005). This is in agreement with the results supporting the concept that $\mathrm{P} 4$ acts as a powerful negative regulator of macrophages (Hunt et al., 1998). Infiltration of the inflammatory cells into the cervical tissue is one of the main histological features observed in the cervix immediately after birth or in the late stages of normal cervical ripening (Knudsen et al., 1997; Stygar et al., 2001; Osman et al., 2003).

It was found out that the number of neutrophils in the external opening of the cervix increased as the pregnancy age increased and the concentrations of progesterone decreased. Neutrophil counts attained a peak in G3 when the plasma concentrations of progesterone were the lowest in comparison with G1 and G2, 
Relationship between plasma concentrations of estradiol-17 $\beta$ and progesterone and the distribution...

indicating a role of these cells in postpartum remodelling of the cervix rather than in the initiation of cervical ripening at parturition (Timmons \& Mahendroo, 2006). This finding is in line with the results reported by some researchers (Owiny et al., 1995; Stygar et al., 2001; Osman et al., 2003).

Inflammatory cells, such as neutrophils and eosinophils, are proposed to play an important role in the synthesis of cytokines and proteolytic enzymes that regulate the ripening process (Mackler et al., 1999). These cells are recruited to affected tissue from circulating blood (Timmons \& Mahendroo, 2006). Several studies reported increased number of neutrophils within the cervical stroma late in pregnancy in rodents and other species (Bokstrom et al., 1997; El Maradny et al., 1997; Timmons \& Mahendroo, 2006). The invasion of neutrophils and monocytes into the cervical stroma is negatively regulated by progesterone. The ability of the progesterone receptor antagonist to partially restore migration of these cells confirms this fact (Timmons \& Mahendroo, 2006).

It was revealed that the presence of eosinophils and basophils in the external opening of the uterine cervix of pregnant buffaloes was negligible. This finding is in line with the results of a study evidencing that the activity of eosinophils was not increased within the cervix until shortly after birth (Timmons \& Mahendroo, 2006). The differential white blood cells counts were within the normal ranges and no abnormality was observed. Examination of the microbiological cultures revealed no abnormality and suggested that changes in the percentage of the inflammatory cells in the external opening of the cervix were due to the changes that occurred in P4 and E2 concentrations.

\section{CONCLUSION}

In summary, this study indicated that the counts of the non-vacuolated and vacuolated epithelial cells, lymphocytes, eosinophils, and basophils did not change significantly in the external opening of the pregnant buffaloes' uterine cervix in the different stages of gestational period, but demonstrated increased counts of neutrophils and macrophages as pregnancy increased and the plasma concentrations of P4 decreased.

\section{REFERENCES}

Ahmadi, M. R., S. Nazifi, \& H. R. Gheisari, 2000. Cytology changes in heifers' cervical mucosae at different phases of the estrus cycle. In: Proceedings from the Fourteenth International Congress on Animal Reproduction, Stockholm, Sweden, p. 52.

Ball, P. J. H. \& A. R. Peters, 2004. Reproduction in Cattle, third edn, Blackwell Publishing, Oxford, UK, pp. 21, 63.

Black, W. G., L. C. Ulberg, H. E. Kidder, J. Simon, S. H. McNutt \& L. E. Casida, 1953. Inflammatory response of the bovine endometrium. American Journal of Veterinary Research, 14, 179-183.

Bokstrom, H., M. Brannstrom, M. Alexandersson \& A. Norstrom, 1997. Leukocyte. Subpopulations in the human uterine cervical stroma at early and term pregnancy. Human Reproduction, 12, 586-590.

Bollwein, H, F. Weber, B. Kolberg \& R. Stolla, 2002. Uterine and ovarian blood flow during the estrous cycle in mares. Theriogenology, 57, 2129-38.

Bosquiazzo, V. L., M. Durando, J. Varayoud, J. G. Ramos, H. A. Rodr'iguez, M. Mũnoz-de-Toro \& E. H. Luque, 2005. Macrophage density in the pregnant rat uterine cervix is modulated by mast cell degranulation. Journal of Reproductive Immunology, 65, 147-158. 
Brown, B. W. \& P. E. Mattner, 1977. Capillary blood flow in the genital tracts of conscious ewes: Cyclic changes and the effect of ovarian hormones. Journal of Endocrinology, 74, 185-191.

Edmonson, A. J., I. J. Lean, L. D.Weaver, T.Farver \& G. Webster, 1989. A body condition scoring chart for Holstein dairy cows. Journal of Dairy Science, 72, 6878.

El Maradny, E., N. Kanayama, H. Kobayashi, B. Hossain, S. Khatun, S. Liping, T. Kobayashi \& T. Terao, 1997. The role of hyaluronic acid as a mediator and regulator of cervical ripening. Human Reproduction, 12, 1080-1088.

Greco, T. L., T. M. Duello \& J. Gorski, 1993. Estrogen receptors, estradiol and diethyilestrilbestrol in early development: The mouse as a model for the study of estrogen receptors and estrogen sensitivity in embryonic development of male and female reproductive tracts. Endocrinology Review, 14, 59-71.

Hertelendy, F., \& T Zakar, 2004. Prostaglandins and the myometrium and cervix. Prostaglandin, Leukotriens and Essential Fatty Acids, 70, 207-222.

Hunt, J. S., L. Miller \& J. S. Platt, 1998. Hormonal regulation of uterine macrophages. Clinical and Developmental Immunology, 6, 105-110.

Isaacson, P. \& D. H. Wright, 1984. Extranodal malignant lymphoma arising from mucosaassociated lymphoid tissue. Cancer, 53, 2515-2524.

Jefferson, W. N., J. F. Couse, E Padilla-Banks, K. S. Korach \& R. R. Newbold, 2000. Content of estrogen receptor is developmentally regulated in reproductive tissues of male and female mice. Biology of Reproduction, 62, 310-317.

Joswig, M., 2000. Wirkungen von Östrogenen auf die Gefäwand: Zelluläre und molekulare Mechanismen. Zeitschrift für Ärztliche Fortbildung und Qualitätssicherung, 94, 189-193.
Junqueira, L. C. U., M. Zugaib, G. S. Montes, O. M. S. Toledo, R. M. Krisztan \& K. M. Shigihara, 1980. Morphologic and histochemical evidence for the occurrence of collagenolysis and for the role of neutrophilic polymorphonuclear leukocytes during cervical dilation. American Journal of Obstetrics and Gynecology, 138, 273-281.

Kelly, R. W, 1994. Pregnancy maintenance and parturition: The role of prostaglandin in manipulating the immune and inflammatory response. Endocrinology Reviews, 15, 684-706.

Klauke, M. \& B. Hoffmann, 1992. Progesterone and estrogen receptors in the myometrium of the cow during the estrous cycle and pregnancy and of the sheep at the time of parturition. Animal Reproduction Science, 29, 195-203.

Knudsen, U. B., N. Uldbjerg, T. Rechberger \& K. Fredens, 1997. Eosinophils in human cervical ripening. European Journal of Obstetrics, Gynecology and Reproduction Biology, 72, 165-168.

Lee, H. Y. \& O. D. Sherwood, 2005. The effects of blocking the actions of estrogen and progesterone on the rates of proliferation and apoptosis of cervical epithelial and stromal cells during the second half of pregnancy in rats. Biology of Reproduction, 73, 790-797.

Mackler, A. M., G. Iezza, M. R. Akin, P. McMillan \& S. M. Yellon, 1999. Macrophage trafficking in the uterus and cervix precedes parturition in the mouse. Biology of Reroduction, 61, 879-883.

Mitchell, M. D., 1984. The mechanism(s) of human parturition. Journal of Developmental Physiology, 6, 107-118.

Nephew, K. P., X. Long, E. Osborne, K. A. Burke, A. Ahluwalia \& R. M. Bigsby, 2000. Effects of estradiol on estrogen receptor expression in rat uterine cell types. Biology of Reproduction, 62, 168-177.

Ohta, Y., T. Sato \& T. Iguchi, 1993. Immuonocytochemical localization of progesterone receptor in the reproductive tract 
Relationship between plasma concentrations of estradiol-17 $\beta$ and progesterone and the distribution...

of adult female rats. Biology of Reproduction, 48, 205-213.

Osman, I., A. Young, M. A. Ledingham, A. J. Thomson, F. Jordan, A. Greer \& J. F. Norman, 2003. Leukocyte density and proinflammatory cytokine expression in human fetal membranes, deciduas, cervix and myometrium before and during labor at term. Molecular Human Reproduction, 9, 41-45.

Owiny, J. R., R. O. Gilbert, C. H. Wahl \& P. W. Nathanielsz, 1995. Leukocytic invasion of the ovine cervix at parturition. Journal of the Society for Gynecologic Investigation, 2, 593-596.

Rajabi, M. R., G. R. Dodge, S. Solomon \& A. R. Poole, 1991. Immunochemical and immunohistchemical evidence of estrogenmediated collagenolysis as a mechanism of cervical dilation in the guinea pig at parturition. Endocrinology, 128, 371-378.

Romans, J. G., J. Varayoud, V. L. Bosquiazzo, E. H. Luque \& M. Munoze de- Toro, 2002. Cellular turnover in the rat uterine cervix and its relationship to estrogen and progesterone receptor dynamics. Biology of Reproduction, 67, 735-742.

Rosenfeld, C. R., 1980. Responses of reproductive and nonreproductive tissues to $17-$ beta-estradiol during ovine puerperium. American Journal of Physiology, 239, E333-E339.

Sato, T, A. Ito, Y. Mori, K. Yamashita, T. Hayakawa \& H. Nagase, 1991. Hormonal regulation of collagenolysis in uterine cervical fibroblasts. Modulation of procollagenase, prostromelysin and tissue inhibitor of metalloproteinases (TIMP) by progesterone and estradiol-17 beta. The Biochemical Journal, 275, 645-650.

Shuanfang, Li., 1994. Relationship between cellular DNA synthesis, PCNA content and sex steroid hormone receptor status in the developing mouse ovary, uterus and oviduct. Histochemistry, 102, 405-413.

Sjoquist, P. O., L. Bjellin \& A. M. Carter, 1977. Blood flow to the genital tract of oestrous and dioestrous guinea-pigs. Jour- nal of Reproduction and Fertility, 51, 8386.

Stanchev, P. H., A. Kunavongkrit, L. E. Edqvist \& H. Eriksson, 1984. Receptors for estrogens and progesterone in the porcine cervix. Theriogenology, 21, 757-766.

Stygar, D., H. Wang, Y. Stjernholm-Vladic, G. Ekman, H. Eriksson \& L. Sahlin, 2001. Co-localization of estrogen receptor and leukocyte markers in the human cervix. Molecular Human Reproduction, 7, 881886.

Taya, K. \& G. S. Greenwald, 1981. In vivo and in vitro ovarian steroidogenesis in the pregnant rat. Biology of Reproduction, 25, 683-691.

Taylor, K. M., C. Allison-Gray, M. M. Joyce, M. David-Stewart, F. W. Bazer \& T. E. Spencer, 2000. Neonatal ovine uterine development involves alterations in content of receptors for estrogen, progesterone, and prolactin. Biology of Reproduction, 63, 1192-1204.

Timmons, B. C. \& M. S. Mahendroo, 2006. Timing of neutrophil activation and expression of proinflammatory markers do not support a role for neutrophils in cervical ripening in the mouse. Biology of Reproduction, 74, 238-245.

Varayoud, J., J. G. Ramos, V. L. Bosquiazzo, M. Mũnoz-de-Toro \& E. H. Luque, 2004. Mast cells degranulation affects angiogenesis in the rat uterine cervix along pregnancy. Reproduction, 127, 379-387.

Wehrend, A., S. Huchzermeyer \& H. Bostedt, 2005. Distribution of eosinophils and mast cells in the cervical tissue of non-gravid mares during dioestrus. Reproduction of Domestic Animals, 40, 562-563.

Yamashita, S., R. R. Newbold, J. A. McLachlan \& K. S. Korach, 1989. Developmental pattern of estrogen receptor content in female mouse genital tracts. Endocrinology, 125, 2888-2896.

Yellon, S. M., A. M. Mackler \& M. A. Kirby, 2003. The role of leukocyte traffic and activation in parturition. Journal of the Soci- 
ety for Gynecologic Investigation, $\mathbf{1 0}$, 323-338.

Zhao, S. \& O. D. Sherwood, 2004. Induction of labor with RU488 (mifepristone) in relaxin - deficient rats: antepartum administration of relaxin facilitates delivery and increases pup survival. American Journal of Obstetrics and Gynecology, 190, 229-238.

Paper received 28.05.2019; accepted for publication 01.11.2019

\section{Correspondence:}

\section{Goli, DVM, DVSc}

Department of Clinical Science,

Faculty of Veterinary Medicine,

Razi University,

P.O. Box: 6715685414,

Kermanshah, Iran

tel: +988338329540 , fax: +98 8338320041

mobile: +989143418361

e-mail: mojtabagoli@yahoo.com;

mojtabagoli@razi.ac.ir 